\title{
Proximate and bioactive contents of some selected Vegetables in Nigeria: Processing and Varietal effects
}

\author{
Adegunwa, M.O ${ }^{1^{*}}$, Alamu, E.O. ${ }^{2}$, Bakare, H.A. ${ }^{1}$ and Oyeniyi, C. ${ }^{3}$ \\ ${ }^{1}$ Department of Foodservices and Tourism, University of Agriculture, Abeokuta, Nigeria \\ ${ }^{2}$ International Institute of Tropical Agriculture, Ibadan, Nigeria. \\ ${ }^{3}$ Department of Home Economics and Hotel Management, Tai Solarin University of \\ Education, ljebu-Ode, Nigeria
}

\begin{abstract}
Leaves of four varieties of vegetable were subjected to two processing methods which are sun drying and blanching. This study aims at assessing the effect of some post harvest treatments on the nutrient, anti-nutrient and anti-oxidant potentials of the leafy vegetables. In this study fresh leaves of Vernonia amygdalina, Basella alba, Telferia accidentalis and Talinium Triangulare were subjected to the processing methods mentioned earlier, the vegetables were blanched at $60{ }^{\circ} \mathrm{C}$. The proximate, bio-active composition (Tannin, Phytate, Vitamin C, and Beta carotene) were subsequently determined. The result of the study shows the various parameters of the vegetable samples. However, the various conventional food processing techniques caused a significant decrease $(\mathrm{P}<0.05)$ in the Vitamin $\mathrm{C}$ and Total Beta Carotene content while it caused little significant increase $(P>0.01)$ in the tannin and phytate content. The processing methods brought about inconsistence change in the proximate result, some samples increase while some decreased. In conclusion, all these vegetables samples have very high nutrient, anti-nutrient and antioxidant potential; however the various conventional post-harvest treatment caused a significant decrease $(\mathrm{P}<0.05)$ in the nutrient and bio-active content, and at the same time caused a significant decrease in the anti-nutrient and antioxidant potential.
\end{abstract}

Keywords: Vegetables, blanching, drying, antioxidant, carotenoids.

\section{INTRODUCTION}

Vegetable means the edible part of plants, generally speaking, a plant part of which is regularly eaten as unsweetened or salted food to human is considered to be a vegetable (Finberg 1973).

The green colour of leafy vegetables is due to the presence of the green pigment "chlorophyll". Chlorophyll is affected by $\mathrm{pH}$ and changes to olive green in acidic condition, and bright green in alkaline condition. Some of the acids are released in steam during cooking, particularly of cooked without a cover (Fayemi 1999).

Fresh vegetables are important foods both from an economic and nutritional point of view and vegetable of all types are valuable part of our diet. They play an important part in maintaining general good health owing to the presence of mineral element and vitamin., no food stored in the leaves; it is only produced there, therefore little protein or carbohydrate is found in green vegetables.
The greener the leaf the larger the quantity of vitamins and minerals present. All these substances help to build teeth, protect the body from disease and regulate the body process on which vitality and good health depend (FAO 2005; Anon et al 2005).

Vegetables are low in calories and packed with vitamins, minerals, antioxidants and phytochemicals.

There is little information on the effect of processing on the nutrient and anti-nutrient content of these vegetables.

\section{MATERIAL}

Vegetables used: Bitter leaf (Vernonia amygdalina), Fluted Pumpkin (Telfeira accidentalis), Water leaf (Talinum triangulae), and Indian Spinach (Basella alba) were used.

Bitter leaf and Indian Spinach were plucked in a vegetable garden in Ibadan while Fluted Pumpkin and Water leaf were obtained from ljebu-Ode market Ogun-State, Nigeria. 
The vegetable were collected fresh, blanching and sun-drying started within 40-60 minutes after buying and plucking.

Processing Techniques: Vegetable were subjected to some conventional food processing techniques as reported by (Yaciuk and Sofose 1981). A portion of $(500 \mathrm{~g})$ of each of the samples were soaked in hot water of $60{ }^{\circ} \mathrm{C}$ for 5 minutes, drained and sun-dried, while another portion were collected fresh and sundried and the remaining served as fresh samples. The sun-drying of the vegetables varies because of the differences in there moisture content. Fluted pumpkin and bitter leaves were dried within 3-4 days while it took Indian Spinach and Water leaf 8-12 days to get fully dried. The dried vegetables were collected and milled to $0.5 \mathrm{~mm}$ sieve size for analysis.

Chemical determination: The moisture content was determined according to the method of AOAC (2004). The Samples were dried at $105^{\circ} \mathrm{C}$ for $3 \mathrm{~h}$ using the preset oven (Fisher Scientific Isotemp Oven, model 655F, Chicago, USA). The method described by AOAC (2004) was employed for ash content determination. The crucible containing the preweighed samples were placed in a heated furnace (Fisher Isotemp Muffle Furnace, model 186A, USA) at $600{ }^{\circ} \mathrm{C}$ for $6 \mathrm{~h}$ after which they were cooled to room temperature in desiccators and weighed. The protein content $(\%$ nitrogen $\times 6.25)$ and fat content were (1g was extracted for ether extract determination using diethyl ether $\left(64{ }^{\circ} \mathrm{C}\right.$ as solvent) determined according to the method of AOAC (2004).

Determination of Tannin: Tannin content was determined by the Colorimetric method described by Kirk and Sawyer (1998). $5 \mathrm{~g}$ sample was dispersed in $50 \mathrm{mls}$ of distilled water and shaken. The mixture was allowed to stand for $30 \mathrm{~min}$ at $28{ }^{\circ} \mathrm{C}$ before it as filtered through Whatman No 42 grade of filter paper, $2 \mathrm{mls}$ of the extract was dispersed into a $50 \mathrm{ml}$ volumetric flask. Similarly $2 \mathrm{ml}$ standard tannin solution (tannin acid) and $2 \mathrm{ml}$ of distilled water were put in separate volumetric flasks to serve as standard and reagent was added to each of the flasks and the $2.5 \mathrm{ml}$ of saturated $\mathrm{Na}_{2} \mathrm{CO}_{3}$ solution added. The content of each flask was made up to $50 \mathrm{mls}$ with distilled water and allowed to incubate at $28{ }^{\circ} \mathrm{C}$ for $90 \mathrm{~min}$. Their respective absorbance was measured in a Spectrophotometer at $260 \mathrm{~nm}$ using the reagent blank to calibrate the instruction at zero.
Determination of Total Phytic acid: Phytate was determined by a combination of two methods. The extraction and precipitation of phytic acid was done according to the method of Wheeler and Ferrel 1971. Iron in the precipitate was then measured according to the method of Makower 1970 . A 4 to $6 \mathrm{Fe} / \mathrm{P}$ atomic ratio was used to calculate the phytic acid content.

Determination of Ascorbic acid content: The amount of vitamin $C$ in samples was determined by Spectrophotometer using a modified method of Akindahunsi and Oboh 1999. About 5-10g of the weighed sample was soaked for $10-15 \mathrm{~min}$ in $25-40 \mathrm{ml}$ $5 \%$ Metaphosphoric acid in the presence of about $2 \mathrm{~g}$ of activated Charcoal. The mixture was centrifuged and supernatant used for the test. Standard solutions of ascorbic acid were prepared by dissolving 40$100 \mathrm{mg}$ of ascorbic acid in $100 \mathrm{ml}$ of $2 \%(\mathrm{w} / \mathrm{v})$ Metaphosphoric acid. A solution of dichloroindophenol (DCIP) in distilled water was prepared and $1.0 \mathrm{ml}$ of this reagent was mixed with $1.0 \mathrm{ml}$ of ascorbic acid. The reaction mixture was measured spectrophotometrically at $265 \mathrm{~nm}$ against a blank containing the Metaphosphoric acid. The results were used for the Calibration curve samples were replaced with the standard ascorbic acid solution and corresponding vitamin C content extrapolated from the curve.

Determination of Total Carotenes in Vegetables: 0.2 $0.3 \mathrm{~g}$ of chopped and homogenous samples were extracted with cold Acetone which was later partitioned with petroleum ether. The ether phase was passed through Neutral Alumina (activity III) packed column. The column was eluted with petroleum ether and the first band was collected into $25 \mathrm{ml}$ volumetric flask.

The extract was read at $450 \mathrm{~mm}$ and total carotenoid content calculated are as follows;

$$
\mathrm{C}(\mu \mathrm{g} / \mathrm{g})=\frac{\mathrm{A} \times \text { Volume }(\mathrm{ml}) \times 10^{4}}{\mathrm{~A}^{1 \%} \times 1 \mathrm{~cm} \times \text { sample weight }(\mathrm{g}) .}
$$

Where $A=$ Absorbance, $A^{1 \%}=$ absorption coefficient of $\beta$-carotene in PE (2592) (Rodriguez-Amaya and Kimura 2004).

Statistical Analysis: The data obtained were subjected to Analysis of Variance (ANOVA) using SAS statistical package. Means were separated using Duncan's Multiple Range Test (DMRT). The least significance difference (LSD) was carried out using Zar 1884. Significance was accepted at $P \leq$ 0.05 . 


\section{RESULTS AND DISCUSSION}

The moisture content of the fresh samples ranged from $60.7 \%$ to $64.5 \%$ and dry matter content ranged from $35.5 \%$ to $39.3 \%$ as presented in Table 1.

The proximate composition of the processed vegetables is shown in Table 2.

The protein content in the fresh vegetables ranged from $20.3 \%$ in $T$. triangulare to $35.7 \%$ in $T$. accidentalis, while in sun-dried sample the content ranged from $23.4 \%$ in $V$. amygdalina to $31.1 \%$ in $T$. accidentalis. In the Blanched and sun-dried samples, the protein content ranged from $19.5 \%$ in $T$. triangulare to $23.4 \%$ in $T$. accidentalis, with a coefficient value of $1.1 \%$ in all.

The fat content in fresh samples ranged from $2.3 \%$ in T. triangulare to $4.8 \%$ in $\mathrm{B}$. alba, while in the sundried samples the fat content ranged from $2.8 \%$ in $T$. accidentalis to $4.7 \%$ in $T$. triangulare and in Blanched samples ranged from $2.7 \%$ in $\mathrm{V}$. amygdalina to $6.7 \%$ in $T$. triangulare with a coefficient value of $3.7 \%$ in all.

The ash content in fresh samples ranged from $9.4 \%$ in $T$. accidentalis to $24.6 \%$ in $T$. triangulare while in sun-dried samples the ash content ranged from $10.8 \%$ in $T$. accidentalis to $25.0 \%$ in $T$. triangulare. In the blanched samples the content ranged from $8.3 \%$ in $B$. alba to $20.9 \%$ in $T$. triangulare with an overall coefficient value of $20.6 \%$.

The tannin content in fresh vegetable used ranged from $1.8 \mathrm{mg} / \mathrm{g}$ in $T$. triangulare to $4.2 \mathrm{mg} / \mathrm{g}$ in $T$. accidentalis, while in sun-dried samples the content ranged from $1.8 \mathrm{mg} / \mathrm{g}$ in $B$. alba to $3.4 \mathrm{mg} / \mathrm{g}$ in $V$. amygdalina. In the blanched samples the tannin content ranged from $1.3 \mathrm{mg} / \mathrm{g}$ in $B$. alba to $3.4 \mathrm{mg} / \mathrm{g}$ in $T$. accidentalis with a coefficient value of $3.0 \%$

The phytate content in Fresh samples ranged from $0.5 \mathrm{mg} / \mathrm{g}$ in both $T$. accidentalis and $T$. triangulare to $0.8 \mathrm{mg} / \mathrm{g}$ in $B$. alba, while in sun-dried samples the phytate content ranged from $0.6 \mathrm{mg} / \mathrm{g}$ in $B$. alba to $0.8 \mathrm{mg} / \mathrm{g}$ in both $T$. accidentalis and $V$. amygdalina. In the blanched samples the content ranged from 0.6 $\mathrm{mg} / \mathrm{g}$ in $B$. alba to $1.0 \mathrm{mg} / \mathrm{g}$ in both $T$. accidentalis and $T$. triangulare. The overall coefficient value is 5.5 $\%$

The vitamin C content ranged from $49.3 \mathrm{mg} / 100 \mathrm{~g}$ in $V$. amygdalina to $104.1 \mathrm{mg} / 100 \mathrm{~g}$ in $T$. accidentalis in fresh samples while the sun-dried samples ranged from $48.0 \mathrm{mg} / 100 \mathrm{~g}$ in $V$. amyghdalina to 61.1 $\mathrm{mg} / 100 \mathrm{~g}$ in $T$. triangulare. The blanched samples ranged from $31.2 \mathrm{mg} / 100 \mathrm{~g}$ in $\mathrm{V}$. amygdalina to 67.8 $\mathrm{mg} / 100 \mathrm{~g}$ in $T$. accidentalis with a coefficient value of $2.7 \%$.

Total Beta carotene in fresh samples ranged from $240.5 \mu^{-1} g^{-1}$ to $263.8 \mu^{-1}$ in $T$. triangulare and $B$. alba while in sun-dried sample Total Beta Carotene ranged from $35.7 \mu \mathrm{gg}^{-1}$ in $T$. triangulare to $159.9 \mu \mathrm{gg}^{-1}$ in $T$. accidentalis and in blanched samples the content ranged from $10.3{\mu \mathrm{gg}^{-1}}^{-1}$ in $B$. alba to $135.2 \mu \mathrm{gg}^{-}$ ${ }^{1}$ in $T$. accidentalis with an overall coefficient values of $6.7 \%$.

Vegetables plays an important role in human diet, they are important source of both digestible and indigestible carbohydrate. They are also good sources of Vitamin C, Beta carotene and other nutrients and are responsible for more subtle feelings of daily well-being and for protection from long-term degenerative disease (Achinewhu 1983; Oboh 2005).

The result of the fresh composition of vegetable used under this experiment shows both the Fresh moisture content (FMC) and fresh Dry matter (FDM) in Table 1.

FMC is the moisture content of the vegetable samples at its fresh state and as indicated in Table 1, $T$. triangulare has the highest moisture content of $64.5 \%$, followed by $T$. accidentalis $63.3 \%$, then $V$. amygdalina $62.2 \%$ and lastly $B$. alba $60.7 \%$. $T$. triangulare level of moisture content was due to the presence of high content of water in the leaves and stems of the plant, the vegetable derives its local name Water leaf due to this (Oboh 2005).

$B$. alba was recorded to have the lowest fresh moisture content of $60.7 \%$ despite its popularity to be an vegetable of high water content but this might likely to be because the $B$. alba (Indian Spinanch) used under this experiment, and did not grow in a place where there is daily flow of water.

The (FDM) fresh dry matter which is the moisture content that was retained by the samples after it was dried. B. alba retained the highest moisture of $39.3 \%$ followed by $V$. amygdalina $37.8 \%$, then $T$. accidentalis $36.7 \%$ and $T$. triangulare $35.5 \%$. the result ranged from $35.5 \%-39.3 \%$ this indicates that $B$. alba retained the highest moisture content after it was dried in its fresh state (i.e. the highest dry matter) and it is because of the amount of nutritional component present in B. alba.

The result of the proximate composition of the vegetable used as shown in table 2 indicate the protein content in the fresh form ranging from $20.3 \%$ in $T$. triangulare to $35.7 \%$ in $T$. accidentalis and this 
values are much higher to that of Cnidoscolus acontifolus that has $7.8 \%$ protein content (Oboh 2005).

However, the various conventional food processing techniques caused little significant difference $(P<0.001)$ in all the vegetables samples used except in $T$. accidentalis leaves that was subjected to sun drying alone, where there was little significant difference .It is worth noting that not all processing techniques could bring about decrease in the protein content, but the little decrease occur in the nutritional content caused by sun drying and blanching could be attributed to the fact that some nutrient were leached off by water during blanching, draining and sun drying (Olusanya 2008). The values for both the processed and unprocessed vegetable under this experiment were higher than the reported value for closely related edible leaves of Solanium meloneana, Solanium acthiopicum (4.8\%) Solanium lycospersocum (2.8\%) and solanium nigruim (3.2 \%), Solanium macrocarpon and Cnidoscolus acontifolics (7.8\%) (Oboh et al 2005).

Sun drying brought about an increase $(P<0.05)$ in the protein content of $T$. triangulare $24.5 \%$ and $\mathrm{B}$. alba $26.4 \%$; these two vegetables samples have common history of high water content. The higher protein content in them could be as a result of more and active nitrogen fixing bacteria giving rise to high nitrogen content, which could result in high amount of

Protein (Oboh 2005).

In addition the various conventional food processing techniques brought about a significance increase $(P<0.05)$ in the fat content. The fat content in the vegetable at its fresh form ranged from $2.3 \%$ in $T$. Triangulare to $4.8 \%$ in $B$. alba while $T$. accidentalis and $V$. amygdalina both has $3.0 \%$ of fat content; the fat content of these vegetable samples are quite high when compared to that of Cnidoscolus acontifolus $1.6 \%$, Solanium macrocarpon (Oboh et al 2005). Solanum lycospersicum (0.6\%), Solanium melaneama (0.4\%) and Solanium anthiopum(0.3\%) (Leung 1968).

The change in decrease and increase of the fat content of those subjected in sun drying were not consistent and it ranged from $2.8 \%$ to $4.7 \%$; however there was a significant increase $(P<0.05)$ in the fat content of the vegetable samples subjected to blanching and sun drying and it was between the range of $2.7 \%$ to $6.7 \%$ indicating $V$. amygdalina has having the lowest fat content after blanching and sun drying.
The Dry Moisture Content (DMC) of the vegetable in its fresh state ranged from $6.5 \%-7.8 \%$; the DMC of sun dried samples ranged from $6.5 \%-10.9 \%$ and the blanched and sun dried samples ranged from $9.2 \%$ $9.8 \%$. The processed vegetables have the highest dry moisture content, but the changes were not consistent.

There is a little significant increase $(P<0.01)$ in the ash content of processed vegetables, especially all those that are subjected to sun drying ranging from $10.8 \%$ in $T$. accidentalis to $25.0 \%$ in T. triangulare. The blanched and sun dried vegetable samples has no significant change except $B$. alba which is $8.3 \%$ and this has a significant decrease $(P>0.05)$ compared to others.

The decrease in the ash content of processed vegetables could be as a result of processing during which some of the inorganic salt in the vegetables might have leached off (Yaciuk and Sofose 1981). While the increase in the ash content could be as a result that some inorganic salt have been trapped in the vegetable during processing (Oboh et al 2005).

Bio-active compound (Tannin, Phytate, Vitamin C and Beta carotene) of vegetables used under this experiment are presented in Table 3.

Phytic acid though considered as an anti - nutritional factor in a common storage of phosphorus in seeds and in few tubers and fruits. The complexities of phytic acid with nutritionally essentials minerals are suggested to be responsible for the anti - nutritional activity (Oboh et al 2005). As shown in table 3, the phytate content of the unprocessed leaves ranged from $0.5 \mathrm{mg} / \mathrm{g}-0.8 \mathrm{mg} / \mathrm{g}$, indicating $B$. alba as the fresh sample that has the highest level of Phytate under this experiment but all these result were low when compared to the phytate content of Cnidoscolus antifolus in its fresh state which was $479.5 \mathrm{mg} / 100 \mathrm{~g}$ and it was the same with that of Solanium macrocarpon leaf (Oboh et al 2005) but $T$. triangulare leaf was recorded to be exceptionally high in phytate content with $2341.1 \mathrm{mg} / 100 \mathrm{~g}$ (Akindahunsi and Oboh 1999).

These result were clearly different from those recorded under this experiment especially with the same kind of vegetable ( $T$. trangulare) which was recorded under this experiment to have $0.5 \mathrm{mg} / \mathrm{g}$ in its fresh state $0.7 \mathrm{mg} / \mathrm{g}$ in sun dried samples and 1.0 $\mathrm{mg} / \mathrm{g}$ in blanched samples.

The difference in the phytate content of the samples could be as a result of soil composition used in 
growing the vegetables; that is if the vegetable are grow on a soil that is very rich in plant nutrients.

There is little significant increase $(P<0.01)$ in the processed vegetable content of sun dried and blanched vegetables, the sun dried samples ranged from $0.6-0.8 \mathrm{mg} / \mathrm{g}$ while the blanched samples ranged from $0.6-1.0 \mathrm{mg} / \mathrm{g}$.

All these values do not agree with the earlier report of Oboh et al 2005, that processing brings out decrease in phytate content of plant foods. Because of all the processing techniques employed in this experiment, blanching and sun-drying cause an increase in the phytate content of the vegetables.

Vegetables in conjunction with fruits and nuts is known to contribute about $91 \%$ of vitamin C, ascorbic acid contributes to the antioxidant properties of vegetables by protecting the membrane erythrocyte, maintaining the blood vessels flexibility and improving blood circulation in the arteries of smokers as well as facilitating the absorption of iron in the body. As shown in Table 5, the vitamin $\mathrm{C}$ content of the fresh vegetables ranged from $49.3 \mathrm{mg} / 100 \mathrm{~g} \mathrm{-} 104.1$ $\mathrm{mg} / 100 \mathrm{~g}$, while the sun-dried samples ranged from 48.0 - $61-1 \mathrm{mg} / 100 \mathrm{~g}$ and the blanched samples ranged from 31.2 - $67.8 \mathrm{mg} / 100 \mathrm{~g}$. These results indicates that there is a significant decreases $(P>0.05)$ in the processed vegetable samples.

The values of some the fresh vegetable used under this experiment are higher than the vitamin $\mathrm{C}$ content of fresh Corchorus olitorus (43.5\%), Solanium macrocarpon (43.5\%) while Cnidoscolus acontifolus $(52.6 \%)$ falls in between.

The various conventional food processing techniques caused a highly significant decrease $(P<0.05)$ in the vitamin $C$ content of all the vegetables, the loss in vitamin $C$ during processing agrees with the earlier report by (Achinewhu 1983, Oboh 2005, Akindahunsi and Oboh 2005) that various conventional food processing methods would bring a loss in vitamin $\mathrm{C}$ content. This loss in vitamin $\mathrm{c}$ during processing could be attributed to the fact that vitamin $\mathrm{C}$ is soluble in water and at the same time not stable in high temperature (Nagy and Smooth 1977). All the processing techniques employed in this research were carried out in water and with high temperature.

Tannin have antioxidants capacities that are much stronger than those of vitamin $\mathrm{C}$ and $\mathrm{E}$. Flavonols and flavonones are flavonoids of particular importance because they have been found to possess antioxidant and free radical scavenging activity in vegetable (Amic et al 2003). The tannin content in the vegetables as shown in Table 5; the content in fresh vegetables ranged from $1.8 \mathrm{mg} / \mathrm{g}$ $4.2 \mathrm{mg} / \mathrm{g}$, while the sun-dried samples ranged from $1.8 \mathrm{mg} / \mathrm{g}-3.4 \mathrm{mg} / \mathrm{g}$ and blanched samples ranged from $1.3 \mathrm{mg} / \mathrm{g}-3.4 \mathrm{mg} / \mathrm{g}$. V. amygdalina was able to retain the same amount of tannin content with its fresh from after it was sun-dried (3.4\%) which indicates it to be the vegetable samples that retained the highest content of tannin after been sun-dried, While $B$. alba retain the lowest amount of tannin (1.8\%) after sun-drying.

$T$. accidenalis that was blanched retained the highest amount of tannin content $(3.4 \mathrm{mg} / \mathrm{g})$, while blanched $B$. alba retained the lowest amount of tannin (1.3 $\mathrm{mg} / \mathrm{g}$ ).

The processing methods does not have much significant difference in the decrease of tannin content because it was not consistence, though some vegetable samples retained tannin to about the same extent but these samples were with different processing methods like (Sun drying) $V$. amygdalina $3.4 \mathrm{mg} / \mathrm{g}$ and (Blanching) $T$. accidentalis $3.4 \mathrm{mg} / \mathrm{g}$ ) and (Sundrying) $B$. alba $1.8 \mathrm{mg} / \mathrm{g}$ and (Blanching) $T$. triangulare $1.9 \mathrm{mg} / \mathrm{g}$ ). The content of these samples are higher than those reported by Oboh 2005 of some commonly consumed green leafy vegetables Nigeria namely Amaranthus cruentus, Ocimum gratissimum, Solanium macrocarpon and Corchous olitorus which is $0.3 \%$ and Struchium sparganophora had $0.1 \%$.

The basis of the increase in sun-dried $T$. triangulare could not be categorically ascertained. However it has been reported that cooking or wet heating could increase the tannin content, likewise blanching (Oboh et al 2003, 2005).

Beta carotene is a member of the carotenoids which are highly pigmented and it is known as a precursor of vitamin A, which implies that it is an essential part of the production process. They are powerful antioxidant protecting the cells of the body from damage caused by free radicals; $\beta$ carotene enhances the function of immune system and has the ability to stimulate cell to cell communication (Olson et al 2001).

The Beta carotene results as shown in Table 5 indicates the fresh samples as having the highest content of Beta carotene in them and this ranged from $240.5 \mu \mathrm{gg}^{-1}$ in T. triangulare to $263.8 \mu \mathrm{gg}^{-1}$ in B. alba, showing that fresh $B$. alba has the highest 
content of Beta carotene and $T$. triangulare the lowest.

The sun-dried samples ranged from $35.7 \mu \mathrm{gg}^{-1}$ in $T$. triangulare to $159.9 \mathrm{\mu gg}^{-1}$ in $T$. accidentalis while the blanched samples recorded the lowest samples that could not retain much Beta carotene showing $B$. alba $10.3 \mu \mathrm{gg}^{-1}$ to $135.2 \mu \mathrm{gg}^{-1} \mathrm{~T}$. accidentalis.

Due to the methods of processing carried out on them, the samples could not retain Beta carotene and this is in agreement with the finding of Olson et al 2001 and FAO 2005 that in food processing carotenoids are fairly resistance to heat, changes in $\mathrm{pH}$, and water leaching since they are fat soluble. They are very sensitive to oxidation which results in both colour loss and destruction of vitamin A activity. Prolong cooking of vegetable decreases the availability of carotenoids by changing the shape of carotenoids from its natural trans-configuration to a cis-configuration (FAO 2005).

However, this result was not in consonance with earlier observations by Kamath et al 2008, that carotene content increase with heat treatment of vegetables.

All these results shows that the methods of processing used has both positive and negative effect on the nutritional composition on the vegetables samples especially with the vitamin $C$ and Beta carotene but it was affected mostly by blanching method.

Though there were some increase in the protein and fat content of the vegetable samples after been processed, the other changes in the nutritional composition were not consistence.

\section{Conclusion}

The leaves of all the vegetables used have a very high nutrient, antioxidant and antinutrient potential; however this study has shown that post-harvest treatment in form of blanching and sun-drying has a significant decrease $(P>0.05)$ on the bio-active compounds of vegetable especially in Beta carotene, Vitamin $\mathrm{C}$ and Tannin.

These processing methods indicates little significant decreases $(P>0.01)$ and little significant increase $(P<0.01)$ in the vegetable samples while some change in these samples were not consistence on the proximate compounds such as protein, ash, fat and dry moisture content. The result varied with the type of processing employed.

\section{REFERENCES}

Achinewhu, S.C.1983. Ascorbic Acid content of some Nigerian, local fruits and vegetables. Qualities plantanum. Plant food for Human Nutrition, 33: 261-266.

Akindahunsi, A.A.and Oboh, G.1999. Effect of some post harvest treatment on the bioavailability of some selected tropical vegetables. La Rivista Italina Delle Sostanze Grasse LXXVI 285-287

Akindahunsi, A.A.and Oboh, G. 2004.Change in ascorbic acid, total phenol and antioxidant activity of sun-dried cormonly consumed vegetables in Nigeria. Nutrition and Health, 18:29-36.

Amic, D.D., Beslo, D. and Trinagistic, N.2003. Structure-Radical Scavenging Activity Relatiohsip of Flavonoids. Croatia Chemcial Acta, 76: 55-61.

Amina; B.O. 2008. Eating Green vegetable. Nigerian Compass Culsine, Nov 22. Pg 43.

Anon; P., Opabode, J.I. and Adegboye O.C. 2005. Application of Biotechnology for the improvement of Nigerian Indegenious leafy vegetables, Africa J. Biotech 4(3): 138-142.

AOAC.2004. Official methods of Analysis, Association of Official Analytical Chemist, Washington D.C.

FAO. 2005. Fruit and Vegetable for health. Report of a joint $\mathrm{FAO} / \mathrm{WHO}$ workshop.

Fayemi, P.O.1999. Nigerian Vegetables. Ibadan: Heinemann Educational Books.

Feinberg. O.1973. Fruit and vegetable processing; general properties of fruits and vegetable chemical composition.

Kamath, A., Platel, K. and Begum, K.2008. Determination of Bio accessibility of $\beta$ carotene in vegetables by in vitro methods. Vol 50.

Kirk, R. and Sawyer, R.1998. Pearson's composition and analysis of foods. Publ. Church Hill Livingstone, Edinbburgh.

Leung, W.W., Busson, F., and Jarden, C. 1968. Food composition table for use in Africa. http://www.fao.org/docrep1003/X6877E/X6877E00.htm

Makower, R.U.1970. Extraction and determination of phytic acid in beans (Phaseolus vulgaris). Cereal Chem, 47: 288. 
Nagy, S.and Smooth, J.M.1977. Temperature and storage effects on percent retention and percent. U.S. recommended dietary allowances of vitamin $C$ in canned single-strength orange juice. J. Agri, Food chem. 25:135-138.

Oboh, G. 2005. Effect of blanching on the antioxidant property of some tropical green leafy vegetable. Food Sci. Tec/LWY, 38: 513-517.

Oboh, G., Akindahunsi, A.A. and Oshali, A.A. 2003. Dynamics of Phytate-Zn balance of Fungi Fermented cassava products (Flour \& Gari). Plants food for Human Nutrition, 58:1-7

Oboh, G., Ekperigin, M.M., and Kazeem.M.I.2005. Nutritional and hemolytic property of egg- plant (Solanum macrocarpon) leaves. J. Food compo. Anal, 18: 153-160.

Olson, A., Christina, W. and Mayne, S.T. 2001Beta carotene and vitamin A.J Medline Plus.
Olusanya, J.O.2008. Essential of foods and Nutrition. Apex books limited. Lagos Nigeria.

Onitilo, M.O., Sanni, L.O., Daniel, I., Maziya-Dixon and Dixon, A. 2007. Physicochemical and functional properties of native starches from cassava varieties in Southwest Nigeria. Journal of food, Agriculture \& Envirinment Vol.5 (3\&4):108-114.

Rodriguez-Amaya, D.B. and Kimura, M. 2004 Harvestplus Handbook for Carotenoid Analysis.

Wheeler, E.I. and Ferrel, R.E. 1971. Methods for Phytic Acid Determination in Wheat and Wheat Fractions. Cereal Chem, 84: 312-320.

Yaciuk, G. and Sofose, J. 1981.Food drying proceeding of a not shop held at Edmonton Albeta, 6th-9th July 1981.

Zar, J.H. 1984.Biostatistician Analysis, Prentice-Hall, Inc. USA 620p. 